\title{
Leaching of Arsenic in Soils Amended with Crushed Arsenopyrite Rock
}

\author{
Kyosuk Lee, Hoyoung Shim, Dongsung Lee, Jae E. Yang', and Dougyoung Chung* \\ Dept. of Bio-environmental Chemistry, Collage of Agriculture and Life Science, \\ Chungnam National University, Deajeon, 305-764, Korea \\ ${ }^{1}$ Dept. of Biological Environment, Kangwon National University, Chuncheon, 200-701, Korea
}

(Received: March 21 2014, Accepted: April 17 2014)

\begin{abstract}
Arsenic and its compounds which is one of the most toxic elements that can be found naturally on earth in small concentrations are used in the production of pesticides, herbicides, and insecticides. Most arsenic that cannot be mobilized easily when it is immobile is also found in conjunction with sulfur in minerals such as arsenopyrite (AsFeS), realgar, orpiment and enargite. In this investigation we observed the leaching of arsenic in soils amended with several levels of gravel size of arsenopyrite collected from a road construction site. Soil and gravel size of arsenopyrite were characterized by chemical and mineralogical analyses. Results of XRF analysis of arsenopyrite indicated that the proportion of arsenate was $0.075 \%\left(w_{t} \mathrm{wt}^{-1}\right)$ while the maximum amount of arsenic in soil samples was $251.3 \mathrm{mg} \mathrm{kg}^{-1}$. Cumulative amounts of effluent collected from the bottom of the soil column for different mixing rate of the gravel were gradually increased where proportion of the gravel mixed was greater than $\mathbf{7 0} \%$ whereas the effluent was stabilized to the maximum after approximately 45 pore volumes of effluent or greater were collected. The arsenic in the effluent was recovered from the soil columns in which the proportion of arsenopyrite gravel was $60 \%$ or greater. The total amount of arsenic recovered as effluent was increased with increasing proportion of gravel in a soil, indicating that the arsenic in the effluent was closely related with gravel fraction of arsenopyrite.
\end{abstract}

Key words: Arsenopyrite, Arsenic, Soil, Leaching, Gravel

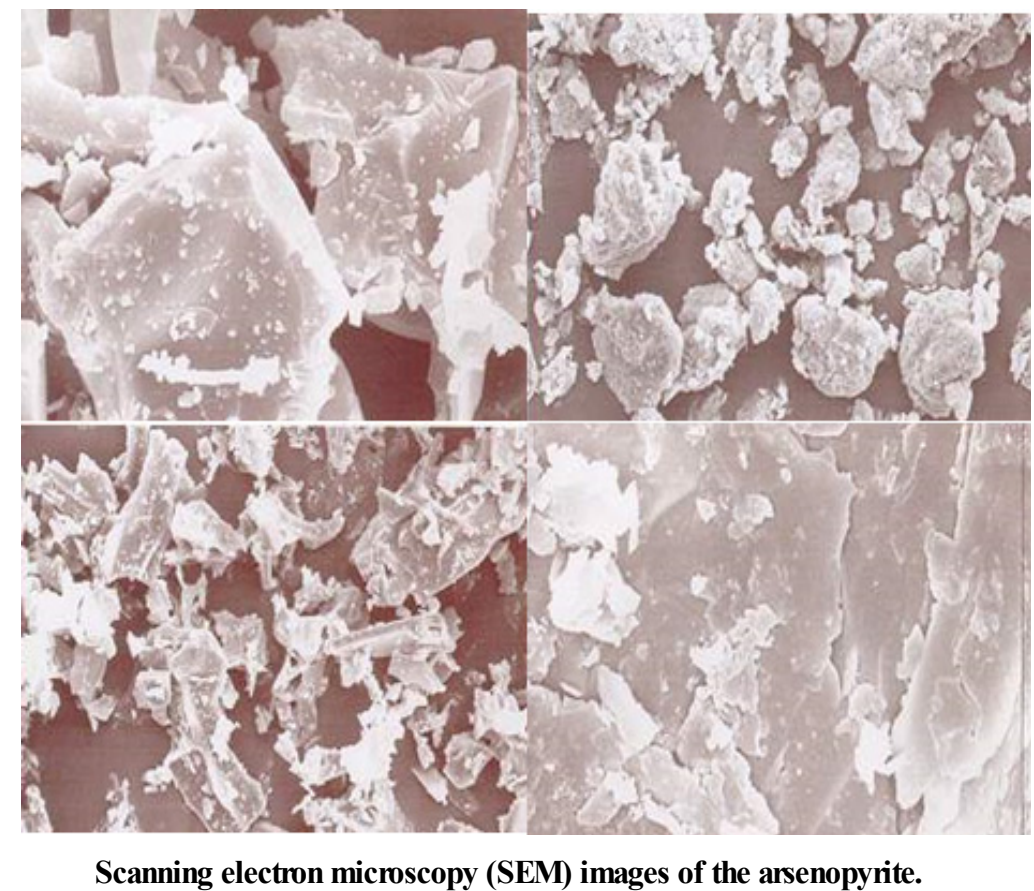

*Corresponding author : Phone: +82428216731, Fax: +82428216739, E-mail: dychung@cnu.ac.kr 


\section{Introduction}

토양은 오염물질의 이동 및 축적이 이루어지는 최종 수 용체로서 중금속을 포함한 오염물질이 유입되는 곳으로 토 양의 특성상 오염으로 인해 기능을 상실하게 되면 복원할 수 없거나 오염정도에 따라 어느 정도 회복이 가능한 곳일 지라도 그 회복에 매우 긴 시간이 소요되는 특징을 지니고 있다. 토양에 유입된 오염물질 중 중금속은 자연적으로 분 해되지 않으며 토양이 산성화되는 경우 쉽게 용출되어 토 양, 지하수, 식물, 인간으로 연결되어 인체에 축적되고 독성 을 나타낼 수 있다 (Adriano, 1986; Park, 2009; Yang, 2009). 비소는 지구의 지각에 널리 분포하는 자연발생 원소로 구리 또는 납을 포함한 광석에 많이 존재한다. 그리고 비소 와 대부분의 비소 화합물은 강한 독성을 보이는 1 급 발암 물 질로 적은 복용 양으로 구토, 설사를 일으키고, 많은 양으로 는 심장박동 이상, 혈관손상을 일으켜 죽음에 이를 수도 있 다 (Rue, 1988).

경상북도 경주, 포항 그리고 울산지역의 지형경관의 특 징을 살펴보면 각력암. 대구층. 유문석 영안산암이 주인 중 생대 백악기 신라통과 화강암. 규장암. 관입암맥의 백악기 불국통, 신생대 3 기 장기통 (당사리안산암)과 연일통 (정자 역암), 신생대 제 4 기 충적층과 중생대 말기 화강암 관입으 로 변성작용을 받아 형성된 변성퇴적암 혼펠스 등으로 구분 된다 (경주 울산지역의 지형경관, 2004). 그리고 이 지역에 서 발견되는 광물로는 자류철석, 자철석, 황비철석, 황철석, 백철석, 섬아연석, 황동광, 휘창연석이 있으며 비철석류와 황 철석은 비소를 함유하고 있다. 이 중 유비철석 (arsenopyrite, $\mathrm{FeAsS}$ )은 비소를 함유하고 있는 대표적인 금속광물이며, 주로 유비철석의 풍화로 비소가 용출된다. 풍화를 받지 않 은 유비철석 내 -1 가 비소가 우세하게 존재하며, 물이나 공 기에 의해 풍화를 받으며 표면에서의 -1 가 비소가 $+3,+5$ 및 +1 가로 변화하게 된다 (Nesbitt, 1995).

Manning and Goldberg (1997)은 $\mathrm{Fe}-$ 산화광물은 $\mathrm{pH}$ 7-10 사이에서는 표면전하가 거의 없으나 $\mathrm{pH}$ 변화에 따라 $\mathrm{Fe}-$ 산 화광물과 $\mathrm{Al}-$ 산화광물 표면에 화학적 결합 또는 리간드교 환 형태로 비소이온의 흡착이 발생한다. 그리고 $\mathrm{Al}-$ 산화광 물은 pH 6 범위에서 영전하점 (point of zero charge, PZC) 이 생성되어 $\mathrm{pH}$ 가 6 이하일 경우 $\mathrm{Al}$-산화광물 표면에 양전 하가 생성되어 비소이온이 흡착된다. 한편 탄산염광물이 존 재하는 토양에서 비소이온은 토양 $\mathrm{pH}$ 가 7 9 범위에서 탄산염 광물에 흡착된다 (Darland, 1997). 그리고 토양에 존재하는 비 소의 경우 음이온형태로 이동하며, 철(산)수산화광물[iron (oxy) hydroxides]이나 철 수산화황산염광물(iron oxyhydroxysulfates) 과 함께 침전되거나 이들 광물의 표면에 수착되어 비소의 거동이 제한된다 (Sun, 1998; Carlson, 2002; Pokrovski, 2002; Dixit, 2003; 정현수, 2008; 이우춘, 2009; 김순오, 2009).
Asta et al. (2010)에 따르면 비소용해량은 토양 $\mathrm{pH}$ 변화와 온도변화에 따라 단위 중량당 입자 표면적과 비례하며 토양 내 비소 함유 광물별 용해도는 토양 $\mathrm{pH}$ 와 용존산소량이 증 가함에 따라 $\mathrm{Ca}$ 형태를 제외한 대부분의 비소의 용해도는 증가한다 (Williamson, 1994; Lengke, 2003; Lengke, 2002). 본 연구는 유비철석에 내재되어 있는 비소의 용출특성을 확 인하기 위해 포화상태의 토주를 이용하여 유비철석의 혼합 비율에 따른 토양으로부터 비소의 용탈 특성을 조사하였다.

\section{Materials and Methods}

시료채취 시료는 경상북도 녹동리 일대 논토양과 산림 지역의 유비철석 파쇄물을 채취하였다. 유비철석으로부터 유래되는 비소의 토양 내 동태를 조사하기 위하여 사용한 토양은 농경지를 중심으로 토양환경보존법의 토양오염공정 시험기준 및 토양 정밀조사지침을 준수하여 각 지점을 대표 할 수 있는 곳을 선정하여 채취하였다. 토양 시료채취는 작 물의 유효심도인 표토 $(30 \mathrm{~cm}$ 이내)에서 채취하였으며, 시 료의 경우 Hand Auger로 6 8지점의 시료를 채취하여 혼합 한 후 4 분법으로 분할한 1 점의 대표성 있는 시료를 채취하 였다.

시료 분석방법 공시토양의 기초조사에서 $\mathrm{pH}$ 와 전기전 도도 (Electrical conductivity : $\mathrm{EC}$ )는 토양과 증류수를 1:5 로 혼합하여 현탁액을 만든 후 측정하였고, 유기물함량 (OM) 은 Wakley-Black법, 양이온치환용량 (CEC)은 Ammonium acetate법에 의해 분석하였다. 토성분석은 토양을 $5 \%$ Sodium hexametaphosphate 용액에 의해 분산시킨 후 ASTM \#152 Hydrometer를 이용해 측정하였다.

비소 분석을 위한 토양시료는 국내 토양오염공정시험기 준 (환경부)에 따라 시료 $3 \mathrm{~g}$ 에 염산 $21 \mathrm{ml}$ 와 질산 $7 \mathrm{ml}$ 를 가 하여 환류냉각방법으로 전처리 하였고, 가용성 비소함량을 확인하기 위해 $1 \mathrm{~N}-\mathrm{HCl}$ 을 이용하였다. 또한 유비철석 시료 는 파쇄장에서 일정크기로 파쇄 된 시료를 6점 채취하여, 토양오염공정시험기준 방법으로 분석하였다. 전처리 된 시 료는 원자흡수분광광도계 (Model : Perkin Elmer AAnalyst $800 \mathrm{GF}-$ Furnace)를 이용하여 측정하였다.

토양 내 비소 동태 측정 토양 내 비소의 동태 측정 방 법으로는 용액 내 이온의 이동을 최적화하기 위해 아크릴로 제작하였다. 컬럼시험을 위한 처리구는 유비철석 작은 입자 크기 $(<2 \mathrm{~mm})$ 를 사용하여 오염물질의 발생을 최대 조건으 로 설정하였다.

농경지와 유비철석의 혼합비율을 0\%부터 $100 \%$ 까지 $10 \%$ 간격으로 총 9단계 (100:0 0:100)로 구분하여 균질하게 혼합한 각각의 시료를 혼합 비율을 기준하여 $870 \mathrm{~g}$ 의 건조 
시료를 직경 $6 \mathrm{~cm}$ 아크릴 컬럼에 자연낙하하여 $35 \mathrm{~cm}$ 로 충 진한 후 충진 된 물질의 표면에 증류수 수두높이를 $5 \mathrm{~cm}$ 로 유지하면서 컬럼의 바닥으로 용출되는 용출수를 포집하여 용출 시간별 비소의 용탈량을 조사하였다.

\section{Results and Discussion}

유비철석과 토양의 비소함량 농경지 토양과 유비철 석의 이화학특성을 조사한 결과 농경지의 $\mathrm{pH}$ 는 중성범위에 해당하는 6.23 정도인 반면 유비철석의 $\mathrm{pH}$ 는 9.61로 강알칼 리에 속하는 것으로 조사되었고, 전기전도도는 $0.29 \mathrm{dS} \mathrm{m}^{-1}$, $0.63 \mathrm{dS} \mathrm{m}{ }^{-1}$, 유기물함량은 $0.98 \%$ 와 $0.01 \%$ 이하이며, 양이온 치환용량은 $6.21 \mathrm{cmol}_{+} \mathrm{kg}^{-1}, 2.95 \mathrm{cmol}_{+} \mathrm{kg}^{-1}$, 토성은 농경지 토양에서 사질양토, 유비철석의 입경분포는 $2 \mathrm{~mm}$ 이상의 자 갈 또는 암석에 해당되었다 (Table 1).

Table 2에서 보는 바와 같이 유비철석 내 비소함유량 조 사 결과를 살펴보면 비소와 철, 황의 함량이 각각 $45.6 \%$, $32.4 \%, 21.2 \%$ 로 거의 대부분의 함량을 차지하고 있으며 그 중 비소의 함량이 약 $45 \%$ 로 함유하고 있다. 그리고 유비철 석과 농경지 토양 시료의 $\mathrm{XRF}$ 분석결과 농경지 토양 토양 의 구성성분인 $\mathrm{SiO}_{2}$ 와 $\mathrm{Al}_{2} \mathrm{O}_{3}$ 로 구성되어있으며 농경지 토양 에서는 비소가 검출되지 않았다. 하지만 유비철석에서는 비 소가 $\mathrm{As}_{2} \mathrm{O}_{3}$ 형태로 존재하였으며 $0.075 \%\left(747 \mathrm{mg} \mathrm{kg}^{-1}\right)$ 함
유된 것으로 조사되었다 (Table 3).

토양 및 유비철석의 중금속 함량 토양시료의 중금속 함량 분석결과 현행 토양오염공정기준 중 비소함량에 적합 하지 않은 지점이 5 곳으로 조사되었고, 중금속 오염 수준은 현행 토양오염공정시험기준과 가용성 중금속 함량을 Table 4에 나타내었다. 채취된 유비철석에서 비소는 최대 268.56 $\mathrm{mg} \mathrm{kg}$ 으로 토양오염우려기준 1지역기준인 $25 \mathrm{mg} \mathrm{kg}^{-1}$ 의 약 10 배로 확인되었다 (Table 5).

유비철석혼합 비율별 투수성과 비소 이동 특성 입경 가적곡선 (grain-size accumulation curve)은 입자의 입도 를 나타내는 하나의 방법으로 횡축에 입자크기를 $\log$ scale 의 입경 (단위 $\mathrm{mm}$ )을 그리고 종축의 산술눈금에 그 입경보 다 작은 입자가 전입자질량에 대하여 차지한 질량 백분율, 즉 체를 사용할 경우를 고려하면 통과질량 백분율을 나타낸 것이다 (Fig. 1).

토양의 입도특성 중 평균입경은 $60 \%$ 입경 D60 (입경가적 곡선에서 통과질량 백분율 $60 \%$ 에 대한 입경)을 기준하고 투 수성에 특히 영향을 주는 입자의 크기 정도는 $10 \%$ 입경 D10 으로 하는데 이것은 유효경이라고도 한다. 한편 균등계수 $\left(\mathrm{C}_{\mathrm{u}}\right)$ 를 기준하여 ASTM 기준 4 번체 잔류량 $50 \%$ 이상이면 자 갈로 분류하며 4 번체 통과량 이 $50 \%$ 이상이면 모래로 간주

Table 1. Physicochemical properties of arsenopyrite and upland soil.

\begin{tabular}{cccccccc}
\hline \hline \multirow{2}{*}{ Category } & $\mathrm{pH}$ & $\mathrm{EC}$ & $\mathrm{OM}$ & \multicolumn{2}{c}{$\mathrm{CEC}$} & \multicolumn{2}{c}{ Particle distribution (\%) } \\
\cline { 5 - 8 } & $(1: 5)$ & $\left(\mathrm{dS} \mathrm{m}^{-1}\right)$ & $(\%)$ & $\left(\mathrm{cmol}_{+} / \mathrm{kg}^{-1}\right)$ & Sand & Silt & Clay \\
\hline Upland Soil & 6.23 & 0.29 & 0.98 & 6.21 & 62.5 & 21.25 & 26.25 \\
Arsenopyrite & 9.61 & 0.63 & $<0.01$ & 2.95 & & \multicolumn{2}{c}{ gravel $>50$} \\
\hline
\end{tabular}

Table 2. Chemical composition of arsenopyrite gravel used in this experiment.

\begin{tabular}{cccccccccc}
\hline \hline \multirow{2}{*}{ Sample } & \multicolumn{4}{c}{ Weight $(\%)$} & \multicolumn{4}{c}{ Atomic (\%) } \\
\cline { 2 - 11 } & As & Fe & S & Co & Bi & Total & As & Fe & S \\
\hline Arsenopyrite & 45.6 & 32.4 & 21.2 & 0.02 & - & 99.22 & 32.51 & 31.47 & 35.13 \\
\hline
\end{tabular}

Table 3. Results of analysis XRF of arsenopyrite and upland soil.

\begin{tabular}{|c|c|c|c|c|c|}
\hline \multirow{2}{*}{ Component } & Arsenopyrite & Upland soil & \multirow{2}{*}{ Component } & Arsenopyrite & Upland soil \\
\hline & \multicolumn{2}{|c|}{$\%\left(\mathrm{wt} \mathrm{wt}^{-1}\right)$} & & \multicolumn{2}{|c|}{$\%\left(\mathrm{wt} w \mathrm{wt}^{-1}\right)$} \\
\hline $\mathrm{Na}_{2} \mathrm{O}$ & 3.24 & 2.64 & $\mathrm{MnO}$ & 0.21 & 0.24 \\
\hline $\mathrm{MgO}$ & 0.64 & 1.88 & $\mathrm{Fe}_{2} \mathrm{O}_{3}$ & 6.41 & 5.88 \\
\hline $\mathrm{Al}_{2} \mathrm{O}_{3}$ & 16.40 & 17.68 & $\mathrm{NiO}$ & 0.0004 & 0.0004 \\
\hline $\mathrm{SiO}_{2}$ & 62.41 & 61.97 & $\mathrm{ZnO}$ & 0.427 & 0.04 \\
\hline $\mathrm{P}_{2} \mathrm{O}_{5}$ & 0.18 & 0.30 & $\mathrm{As}_{2} \mathrm{O}_{3}$ & 0.075 & - \\
\hline $\mathrm{SO}_{3}$ & 1.98 & 0.34 & $\mathrm{PbO}$ & 0.007 & 0.009 \\
\hline $\mathrm{K}_{2} \mathrm{O}$ & 4.60 & 3.71 & LOI & 1.00 & 0.994 \\
\hline $\mathrm{CaO}$ & 2.30 & 4.28 & Total & 100 & 100 \\
\hline
\end{tabular}


Table 4. Concentrations of heavy metals in the soil from area.

\begin{tabular}{|c|c|c|c|c|c|c|}
\hline \multirow{2}{*}{\multicolumn{2}{|c|}{ Classification }} & As & $\mathrm{Cd}$ & $\mathrm{Cu}$ & $\mathrm{Pb}$ & $\mathrm{Zn}$ \\
\hline & & \multicolumn{5}{|c|}{ 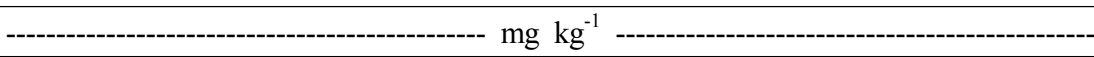 } \\
\hline \multirow{3}{*}{ ES $07400.1^{*}$} & Maximum & 251.33 & 3.97 & 52.83 & 107.08 & 182.88 \\
\hline & Minimum & $\mathrm{ND}^{* *}$ & 0.80 & ND & 5.70 & 29.37 \\
\hline & Average \pm SD & $13.4 \pm 28.4$ & $2.14 \pm 0.72$ & $9.23 \pm 7.51$ & $24.3 \pm 18.2$ & $77.9 \pm 32.4$ \\
\hline \multirow{3}{*}{ Available } & Maximum & 6.78 & 1.83 & 16.66 & 24.27 & 84.90 \\
\hline & Minimum & ND & ND & 0.10 & 0.34 & 0.24 \\
\hline & Average \pm SD & $1.13 \pm 1.36$ & $0.11 \pm 0.20$ & $1.84 \pm 2.08$ & $5.54 \pm 4.14$ & $7.28 \pm 12.5$ \\
\hline
\end{tabular}

* : Korea environmental standard method

** : Not detected

Table 5. Concentrations of heavy metals in gravel fractions of crushed arsenopyrite rock.

\begin{tabular}{ccccccc}
\hline \hline \multirow{2}{*}{ Classification } & $\mathrm{As}$ & $\mathrm{Cd}$ & $\mathrm{Cu}$ & $\mathrm{Pb}$ & $\mathrm{Zn}$ \\
\cline { 3 - 6 } & Maximum & - & 2.76 & 35.28 & 51.5 & 201.06 \\
\hline \multirow{3}{*}{ ES 07400.1 } & Minimum & 16.04 & 2.06 & $<0.01$ & 20.32 & 79.14 \\
& Average \pm SD & $95.3 \pm 88.1$ & $2.32 \pm 0.25$ & $8.19 \pm 13.52$ & $32.98 \pm 11.9$ & $134.34 \pm 50.7$ \\
\hline
\end{tabular}

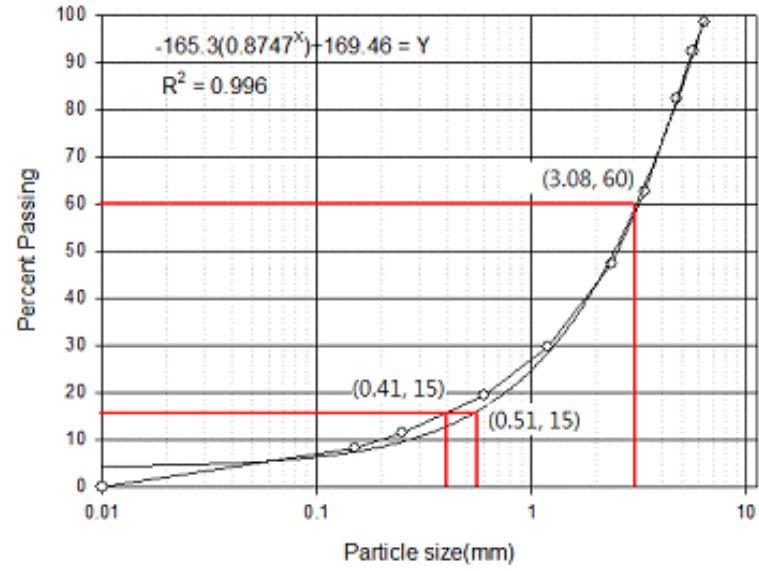

Fig. 1. Grain-size accumulation curve of gravel fraction of the crushed arsenopyrite rock.

한다. 유비철석 입자크기의 입경가적곡선를 조사한 결과 입 자크기는 최대 $11.2 \mathrm{~mm}$ 이하의 크기로 조사되었으며 이를 기준으로 입자분포균질성을 조사한 결과 균등계수는 11.46 으로 비균등범위에 속하는 것으로 조사되었다

유비철석 혼합비율별 투수성을 조사한 결과 유속은 유비 철석 혼합비율이 증가함에 따라 초기 용출수를 포집한 후 50 시간 정도 지난 후 안정화되어 $7.00 \times 10-5 \mathrm{~cm} \mathrm{sec}^{-1}$ 에서 $1.76 \times 10-4 \mathrm{~cm} \mathrm{sec}^{-1}$ 로 조사되었으며 유비철석 혼합비율이 증가함에 따라 안정화된 투수속도에 도달하는 시간이 증가 하였다 (Fig. 2). 안정화 된 투수에 도달하는 시간별 누적용 수량은 유비철석혼합비율이 증가함에 따라 상대적 용출수 량도 증가하는 것으로 조사되었으며 (Fig. 3), 이것은 토양

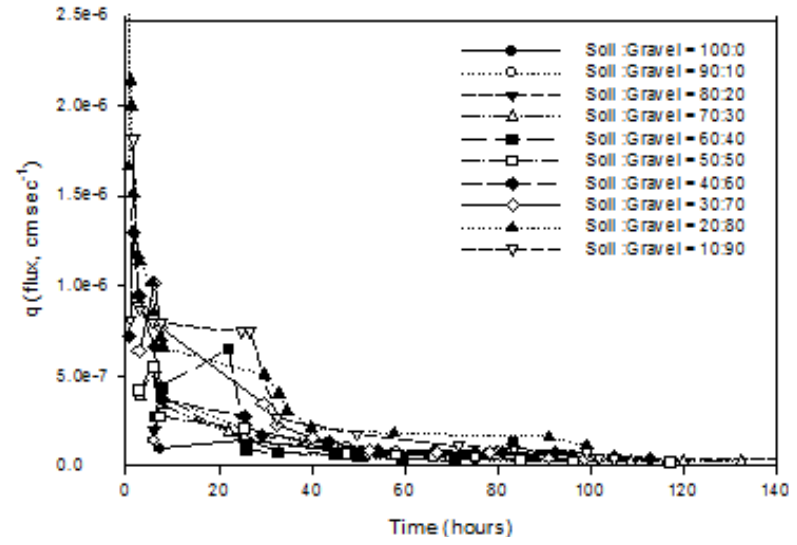

Fig. 2. Hydraulic conductivity of the soil column for different mixing rate of the gravel.

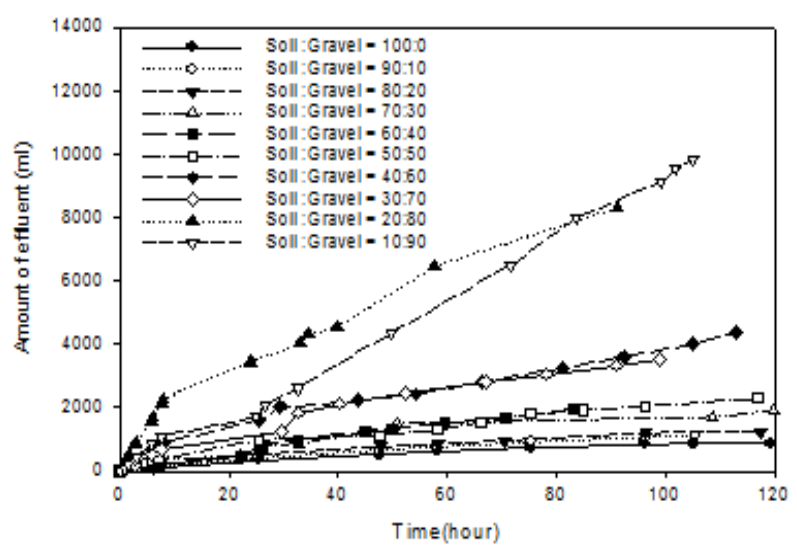

Fig. 3. Cumulative amount of effluent collected from the bottom of the soil column for different mixing rate of the gravel. 
내 혼합된 유비철석으로 인해 발생된 공극이 투수에 의해 안정화되는 과정이 증가하는 것이며 혼합비율이 증가함에 있어 공극의 크기도 증가하여 용출수량도 증가하는 것이다.

한편 공극수량별 용출수의 $\mathrm{pH}$ 조사 결과 농경지토양 보 다 높은 7.4 정도로 알칼리성 특성을 보여주었으며 비소의 토양입자 표면에 흡착되는 비소양은 매우 낮은 것으로 추정 되며, $\mathrm{EC}$ 값을 조사한 결과 공극수량이 증가함에 따라 급격 히 감소하여 약 7.2 공극수량부터 안정화되는 것으로 조사 되었고 유비철석혼합비율이 증가함에 따라 안정화에 도달 하는 시간이 많이 소요되는 것으로 조사되었다.

Fig. 4와 Fig. 5은 용출수에서 비소가 발견된 유비철석 혼합비율이 $60 \%, 70 \%, 80 \%, 90 \%$ 인 토주의 용출수내 비소 용출특성과 용출된 총량을 비교한 것이다. 용출수내 최초 비소는 약 4.5, 4.1, 1.73, 1.02 공극수량부터 조사되었으며 이는 유비철석의 혼합비율이 $60 \%$ 부터 $90 \%$ 로 증가함에 따 라 용출속도가 증가하는 것으로 조사되었다. 한편 최대 비

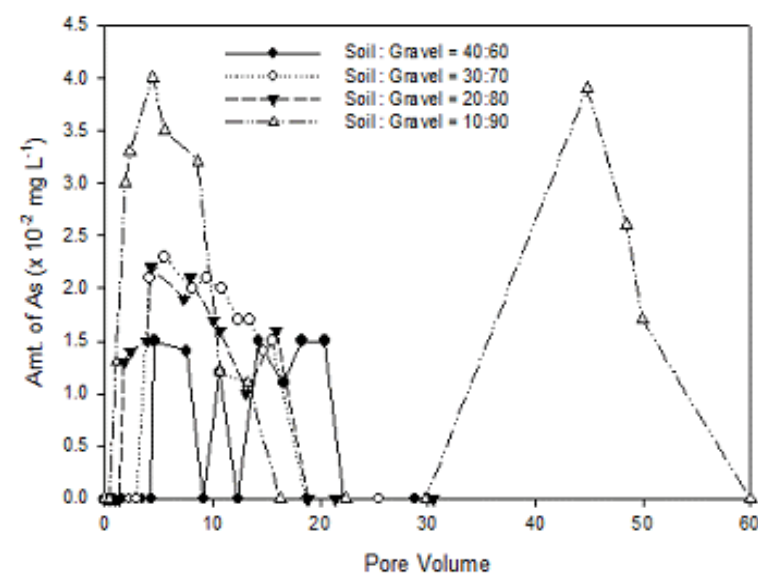

Fig. 4. Amount of arsenic recovered from the effluent collected from the bottoms of the soil columns amended with gravel raining from 60 to $90 \%$ for soils.

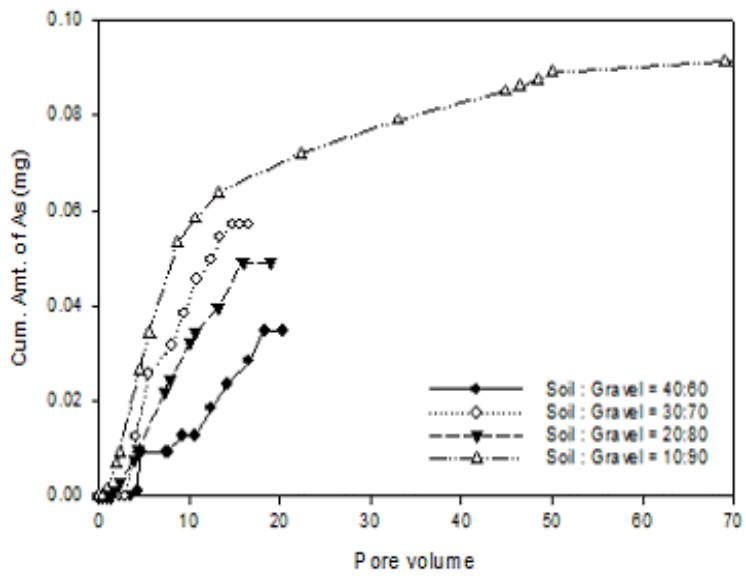

Fig. 5. Cumulative amount of arsenic recovered from the effluent collected from the bottoms of the soil columns amended with gravel ranging from 60 to $90 \%$ for soils.
소 용출에 도달하는 공극수량은 유비철석이 $90 \%$ 혼합된 토 양에서 약 60 공극수량으로 조사되었으며 특히 유비철석이 $90 \%$ 혼합된 토주의 경우 공극수량 약 13.3 부터 30 까지의 용 출수내에는 비소가 검출되지 않았으나 이후 약 45 공극수량 부터 60 까지 용출수에서 비소가 검출되었다. 유비철석 혼합 비율별 비소의 최대 용출량을 조사한 결과 유비철석이 $90 \%$ 혼합된 토주에서 최대 $0.0913 \mathrm{mg}$ 이 용출되어 이를 토주의 충진 된 토양으로 환산 시 약 $0.1049 \mathrm{mg} \mathrm{kg}^{-1}$ 이며 $60 \%$ 의 경 우 $0.0398,70 \%$ 는 $0.0655,80 \%$ 는 0.056 이며 순수한 유비철석 양을 기준 시 용출량은 유비철석혼합비율이 $60 \%$ 에서 $90 \%$ 로 증가함에 따라 각각 $0.066,0.093,0.070,0.1049 \mathrm{mg}$ $\mathrm{kg}-1$ 으로 추정된다. 한편 $80 \%$ 의 경우 $70 \%$ 혼합비율보다 낮게 조사되었는데 이는 토양에 혼합되는 유비철석의 입경 혼합비율 차이에 의한 것으로 추정된다.

\section{Conclusion}

유비철석이 보유하고 있는 중금속인 비소에 대해 조사한 결과 인근 지역의 토양시료 중 일부의 시료에서 토양오염공 정시험법의 토양오염우려기준을 초과하는 결과가 확인되었 다. 유비철석과의 관계를 확인하는 과정에서 유비철석에는 비소, 철, 황의 함량이 대부분을 차지하였고, 수소이온농도 는 강염기에 가까워 수소이온농도와 비소의 용해도가 반비 례 관계이므로 유비철석의 용해도는 낮을 것으로 판단된다.

유비철석 혼합비율별 입경가적곡선을 이용한 입자의 입 도를 확인한 결과 입자크기는 최대 $11.2 \mathrm{~mm}$ 이하의 크기로 입자분포균질성을 조사한 결과 균등계수는 11.46 으로 비균 등범위에 속하는 것으로 확인하였다. 유비철석에 포함된 비 소의 용해도는 입자표면적과 비례하고 수소이온농도에 반 비례관계를 보이는 것으로 알려져 있지만 유비철석 및 파쇄 물에 대한 오염평가와 지하수 용출에 대한 용출시험으로 확 인한 결과 용출수내 최초 비소의 함량은 약 $4.5,4.1,1.73$, 1.02 공극수량으로 부터 조사되었으며 유비철석의 혼합비 율이 $60 \%$ 부터 $90 \%$ 로 증가함에 따라 유비철석으로 인한 공 극의 크기가 커져 용출속도가 증가하는 것으로 판단된다.

유비철석 혼합비율별 비소의 최대 용출량을 조사한 결과 유비철석의 혼합량이 높을수록 용출되는 비소의 양이 높아 져 최대 $0.0913 \mathrm{mg}$ 이 용출되어 충진된 토양으로 환산시 약 $0.1049 \mathrm{mg} \mathrm{kg}^{-1}$ 이며, $80 \%$ 와 $70 \%$ 혼합시 각각 0.0700 .1049 $\mathrm{mg} \mathrm{kg}{ }^{-1}$ 이며 $0.0930 .1049 \mathrm{mg} \mathrm{kg}^{-1}$ 으로 낮게 조사된 이유는 토양에 혼합되는 유비철석의 입경혼합비율 차이에 의한 것 으로 추정된다. 토양입자 표면에 흡착되는 비소양은 매우 낮을 것으로 추정되며, 용출수 내 비소의 용출량도 적은 것 을 확인되었다. 유비철석 내의 비소는 대부분이 용출되어 나오지 않고 유비철석의 비소함량 중 최대 $0.13 \%$ 만 용출이 가능한 것으로 평가되었다. 


\section{References}

Alam, M.G., G. Allison, F. Stagnitti, A. Tanaka, and M. Westbrook, 2002. Metal concentrations in rice and pulses of Samta villiage, Bagladesh, Bull. Environ. Contam. Toxicol. 69, 323-329.

Adriano, D.C. 1992. Biogeochemistry of Tracemetals. Lewis Publishers.

Asta, M.P., C. Ayora, G. Román-Ross, J. Cama, P. Acero, A.G. Gault, J.M. Charnock, and F. Bardelli, 2010. Natural attenuation of arsenic in the Tinto Santa Rosa acid stream (Iberian Pyritic Belt, SW Spain): The role of iron precipitates. Chemical Geology 271, 1-12.

Burton, E.D., Bush, R.T., Johnston, S.G., Watling, K., Hocking, R.K., Sullivan, L.A., and Heber, G.K. Sorption of arsenic(V) and arsenic(III) to schwertmannite. Environ. Sci. Technol. 2009, 43, 9202-9207.

Carlson, S.M., L.J. Moses, and C. Breton, 2002. How specific is the relation between executive function and theory of mind? Contributions of inhibitory control and working memory. Infant and Child Development, 11, 73-92.

Darland, J.E., and W.P. Inskeep. 1997a. Effects of pH and phosphate competition on the transport of arsenate. J. Environ. Qual. 26: 1133-1139.

Darland, J.E., and W.P. Inskeep. 1997b. Effects of pore water velocity on the transport of arsenate. Environ. Sci. Technol. 31:704-709.

Dixit, V.D., M. Mielenz, D.D. Taub, and N. Parvizi, 2003. Leptin induces growth hormone secretion from peripheral blood mononuclear cells via a protein kinase C- and nitric oxidedependent mechanism. Endocrinology 144 5595-5603.

CHIFAMBA, J. The reductive decomposition of refractory sulphide concentrates for the recovery of precious metals, gold and silver. MPhil Thesis, University of Zimbabwe 1996.

CSERVNYAK, I. Electrochemical reduction of pyrite in acidic aqueous electrolytes. PhD Thesis, University of London, 1994.

Egal, M., C. Casiot, G. Morin, M. Parmentier, O. Bruneel, S. Lebrun, and F. Elbaz-Poulichet, 2009. Kinetic control on the formationof tooeleite, schwertmannite and jarosite by Acidithiobacillus ferroxidans strains in an As(III)-rich acid mine water. Chem. Geol. 2009, 265, 432-441.

Ryu, H.L., Y.S. Suh, S.H. Jun, M.H. Lee, S.J. YU, S.N. Hur, and S.Y. Kim, 1988. A sterdy on the natural content of heavy metals in paddy soil and brown rice in korea. National Institute of Environmental Reasearch.

Huang, S.S., Q.L. Liao, M. Hua, 2007. Survey of heavy metal pollution and assessment of agricultural soil in Yangzhong district, Jiangsu Province, China, Chemosphere 67, 2148-2155.

Jeong, H.S., W.C., Lee, H.G., Cho, and S.O. Kim, 2008. Study on adsorption characteristics of arsenic on magnetite. J. Miner. Soc. Korea, 21(4), 425-434.

IARC (International Agency for Research on Cancer). 2004
Some drinking-water disinfectants and contaminants, including arsenic. IARC Monographs on the Evaluation of Carcinogenic Risks to Human. Volume 84, WHO, Geneva, Greece.

Kolodziej, B. and Z. Adamski, 1990. Dissolution of sphalerite in aqueous hydrochloric acid solutions under reduction conditions. Hydrometallurgy, 24, 393-406.

Korean. Soil Sci. Fert, 2012, Report of risk assessment according to embankment of the rock in the tunnel.

Lee, M.H., J.C. Choi, and J.W. Kim, 2003. Distribution and remediation design of heavy metal contamination in farmland soils and river deposits in vicinity of the Goro abandoned mine. Korea Society of Economic and Environmental Geology 36:89-101.

Lengke, M.F. and R.N. Tempel, 2002. "Reaction rates of natural orpiment oxidation at 25 to $40 \mathrm{C}$ and $\mathrm{pH} 6.8$ to 8.2 and comparison with amorphous As2S3 oxidation." Geochimica et Cosmochimica Acta 66(18): 3281-3291.

Lengke, M.F. and R.N. Tempel, 2003. "Natural realgar and amorphous AsS oxidation kinetics." Geochimica et Cosmochimica Acta 67(5): 859-871.

Manning, B.A., and S. Goldberg, 1997a. Arsenic(III) and arsenic(V) adsorption on three California soils. Soil Sci. 162:886-895.

Manning, B.A., and S. Goldberg, 1997b. Adsorption and stability of arsenic(III) at the clay mineral-Water interface. Environ. Sci. Technol. 31:2005-2011.

Ministry of Environment, 2009. Korea environmental standard method.

Muhammad sadiq, 1997. Arsenic chemistry in soils : Overview of thermodynamic predictions and field observations. Water, Air, and Soil Pollution 93:117-136.

Park, S.W., Yang, J.S., R, S. W., Kim, D. Y., Shin, J. D., Kim, W. I., Choi, J. H., Kim, S. L., Andrew, F. S. (2009) Uptake and Translocation of Heavy Metals to Rice Plant on Paddy Soils in "Top-Rice" Cultivation Areas. Korean Journal of Environmental Agriculture 28(2):131-138.

Pokrovski, G.S., R. Gout, J. Schott, A. Zotov, and J.C. Harrichoury, 1996. Thermodynamic properties and stoichiometry of As(III) hydroxide complexes at hydrothermal conditions. Geochimica Cosmochimica Acta, 60(5):737-749.

Raven, K.P., A. Jain, and R.H. Loeppert, 1998. Arsenite and arsenate adsorption on ferrihydrite: kinetics, equilibrium and adsorption envelopes. Environmental Science and Technology 32, 344-349.

Kim, S.O., W.C. Lee, H.S. Jeong, and H.G. Cho, 2009. Adsorption of Arsenic on Goethite. J. Miner. Soc. Korea, 22(3), 177-189.

Smedley, P.L., D.G. Kinniburgh, 2002. A review of the source, behaviour and distribution of arsenic in natural waters. Appl. Geochem. 17, 517-568.

Sullivan, L.A., and R.T. Bush, 2004. Iron-precipitate accumulations associated with waterways in drained coastal acid sulfate soil landscapes of eastern Australia. Marine Freshwater Res. 55, 
$727-736$.

Sun, X. and H.E. Doner, 1998. Adsorption and oxidation of arsenite on goethite. Soil Science, 163, 278-287.

Wenzel, W.W., N. Kirchbaumer, T. Prohaska, G. Stingeder, E. Lombi, and D.C. Adriano, 2001. Arsenic fractionation in soils using an improved sequential extraction procedure. Analytica Chimica Acta 436:309-323.

Williamson, M.A. and J.D. Rimstidt, 1994. Geochim. Cosmochim. Acta 58, 5443-5454.

Lee, W.C., H.S. Jeong, J.Y. Kim, and S.O. Kim, 2009. Study on Adsorption Features of Arsenic onto Lepidocrocite. J. Econ. Environ. Geol., 42(2), 95-105.
Yang, J.E., S.J. Oh, T.H. Kim, S.C. Kim, D.K. Kim, and J.S. Lee, 2009. Remediation of Cd-Contaminated Paddy Soil by ayer Reversing Management Combined with Zero-valent Iron and Lime. International Symposium on Mine Reclamation. 347-350. Jeon, Y.G., 2004. Topographic landscape in Gyengju and ulsan. Seo, Y.J., J. Choi, Y.J. Kang, M. Park, K.S. Kim, Y.H. Lee, and Sridhar Komarneni, Arsenic Movement in the Soils around a Closed Zinc Mine. Korean J. Soil Sci. Fert. 43(1), 51-59 (2010).

Zobrist, J., P.R. Dowdle, J.A. Davis, and R.S. Oremland, 2000. Mobilization of arsenite by dissimilatory reduction of adsorbed arsenate. Environ mental Science and Technology 34:4747-4753. 